\title{
Knowledge of Ladunni in the Story of Moses and Khidhir in the Review of Isyari Shufi's Interpretation
}

\author{
Hermansyah $^{1}$, Sunandar Alwi ${ }^{2}$, Yeni Ratna Yuningsih ${ }^{3}$, Sri Mulyati ${ }^{4}$, \\ Ahmad Syahid ${ }^{5}$, Zainun Kamaluddin Faqih ${ }^{6}$ \\ \{hms6746@gmail.com ${ }^{1}$, muhammadsunandaralwi@live.undip.ac.id², yeniratnayuningsih@uinjkt,ac,id ${ }^{3}$, \\ sri.mulyati@uinjkt.ac.id ${ }^{4}$, ahmad.syahid@uinjkt.ac.id ${ }^{5}$, zainun.kamaluddin@uinjkt.ac.id ${ }^{6}$ \} \\ Graduate School of UIN Syarif ${ }^{1}$, Universitas Padjadjaran ${ }^{2}$, UIN Syarif Hidayatullah Jakarta ${ }^{3456}$
}

\begin{abstract}
The story is one of the ways in the Qur'an to convey its teachings so that it is easy to understand and touches the heart. Among these stories is the story of Prophet Moses studying to Khidhir, a pious man. This story is explained in Surah Al Kahf verses 60-82. And the scholars of Sufism and scholar of interpretation with the style of isyari shufi state that the knowledge possessed by Khidhir is different from the knowledge possessed by Moses so that Moses was ordered by Allah to study it. This knowledge is known as ladunni knowledge, which is usually studied from the point of view of Sufism. So this paper is an attempt to reveal the journey of the prophet Moses to learn ladunni knowledge from Khidhir in the view of the scholarly interpretation of the isyari shufi style. There were 3 incidents where Moses learned ladunni knowledge from Khidhir. Namely when on the ship Khidhir perforated the ship, then the incident of the killing of a small child they met and the last one was enforcing a wall that almost collapsed in a village whose inhabitants were stingy. These events confirmed that Khidhir indeed possessed ladunni knowledge from Allah which Moses did not. Where the prophet Moses always denied what was done by Khidhir because according to the science of the Shari'a that Moses had, everything was contrary to what Khidhir did. Khidhir's ladunni knowledge was revealed when Moses and Khidhir separated because Moses could not be patient to wait for an explanation from Khidhir. And it was only when Khidhir explained that Moses realized that what Khidhir was doing was all right.
\end{abstract}

Keywords: Ladunni Science, The Story of Moses and Khidhir, Tafsir Isyari Shufi's

\section{Introduction}

Indeed, the knowledge that Allah teaches His servants has 2 types of knowledge, the first is called muktasab which is knowledge obtained by a servant in earnest in learning it and the second type of science is ladunni knowledge which is a science that is merely the eyes of Allah give directly to His servants he wants.[1, p. 3/3977]

And the term ladunni science is very closely related to the story of the Prophet Moses and Khidhir contained in Surah Al Kahfi verses 60-82, especially in verse 65 which réc. "And we teach him knowledge from our side ".

From the from the worien which means from our side, namely Allah. So Allah taught him knowledge from His side directly, without learning from anyone. [2, p. 3/2004] 
The majority of commentators agree that what is meant by a personal pronoun in the word و وَعَلَّنَناءُ $\quad$ is Khidhir, a pious servant. So Allah has taught Khidhir a knowledge from His side or the science of ladunni. [3, p. 2/199]

Imam Al Alusy said in his interpretation Ruhul Maany when interpreting the verse:

"According to Jumhur scholars, he is Khidhir. But some say he is Ilyas, and some say: he is an angel. But this opinion is foreign and inner as explained by Muslim sharia. The truth is as evidenced by the authentic news he is Khidhir, and given the name Khidhir, as issued by Bukhari and others from the Prophet: from below then turns green".[4, p. 15/432]

So it is clear that the servant who was taught the science of ladunni was Khidhir and he was in the eyes of Allah more pious than Moses so that Moses needed to study him. [5, p. $13 / 334]$

\section{Background Moses Learned Ladunni Knowledge From Khidhir}

The book of Isyari tafsir which is quite popular, namely Al Bahrul Madid, explains the background why Moses needed to learn this knowledge. Because the knowledge that Moses possesses is shari'ah knowledge, while Khidhir's knowledge is ladunni knowledge.

Ibn Ajibah, the writer of the Isyari commentary, said: Because Moses' journey to study was when Moses was able to defeat Pharaoh by drowning Pharaoh and his soldiers. Then Allah ordered Moses to remind his people of this great blessing. Then Moses carried out Allah's command by giving a sermon before the Children of Israel so that it touched the hearts of his people and then many of them shed their tears after hearing the Prophet Moses' sermon. Then finally they asked who was the most 'pious human being? So Moses replied: I am the most 'pious.[6, p. 4/175]

It turns out that this quality is not liked by Allah. So we can learn that when we are given a lot of knowledge by Allah, we should not feel the most 'pious or know the most, because this quality is not disliked by Allah. The attitude favored by Allah is a Humility attitude by relying on that knowledge is from Allah and Allah knows everything. We as His servants have limited knowledge.

Therefore Allah ordered Moses to always be humble. For that Allah showed Moses that there was a servant who was smarter than Moses and that the servant was very mysterious to meet him. This servant is Khidhir, namely the pious servant whom Allah has given mercy to and is taught the knowledge from Allah's side, namely ladunni knowledge.[7, p. 65]

So finally Moses was also determined to learn from the servant. And the meeting with him took place.

This is explained in the hadith narrated by Bukhari and Muslim from the hadith of Ibn Abbas from Ubay bin Ka'ab that he heard the Messenger of Allah saying:

"Verily, Moses one day stood at a sermon amid the Children of Israel, then was asked who was the most pious human being? Then Moses answered: Me! Then Allah reproached him when he did not return knowledge to Allah glory be to Him. So Allah revealed to him that there was a servant who lived at the meeting of 2 seas, he was more 'pious than you 2 seas he is more pious than you. [8, p. 8/274]

After the Prophet Moses heard Allah's rebuke to him, that there was His servant who lived at the meeting of the two seas more 'pious of him, then the Prophet Moses was eager and determined to learn from the servant, as God explained : 
"And (remember) when Moses said to his student:" I will not stop (walk) before reaching the meeting of two seas, or I will walk even for years ".[9, p. 216]

In the narration of Ubay explained, that Moses asked his Lord, saying :

"O my Lord, how is the way to meet him? Allah said: you must carry fish in the basket, wherever the fish is gone you will find it.". [10, p. 8/564]

Then Moses finally departed to meet the righteous servant accompanied by his pupil Yusya bin Nun and they brought the dead fish to salt until they reached the rocks and they descended. [11, p. 4/322]

Then they both put their heads on the stone so that the prophet Moses fell asleep first, to rest for a while because he had traveled quite a distance. And it turns out that the fish they brought in the container suddenly thrashed and moved and lived, then went into the sea. Allah made a flow of water to make it easy for fish to enter the sea.

Yusya was stunned to pay attention to the greatness of God to raise the dead fish. After witnessing a truly amazing and extraordinary event, Yusya also fell asleep. But when awake, he forgot to tell the prophet Moses alaihis salam. They then resumed their day and night trips and the next morning, the Prophet Moses said to Yusya :

$$
\text { آتِنَا غَدَاعَنَا لَقَْْ لَقِينَا مِنْ سَفَرِنَا هُذَا نَصَبًا }
$$

"Bring our food here, in fact, we have felt exhausted because of our journey." [12, p. $3 / 528]$

The student Yusya said to the Prophet Moses,

The student replied: "Do you know (O teacher) when we looked for shelter on the rock I forgot (told about) the fish and no one made me forget to tell it except shaitan and the fish took its way to the sea in a very strange way. "[13, p. 3207]

Moses immediately remembered something when God stated that wherever the fish was lost, you would meet the servant. And Moses soon realized that they had found a meeting place with the servant of God he was looking for. So the two of them decided to turn around to return to that place, that is, on the rock that had been their previous stop, where two oceans met Moses said : [14, p. 4/135]

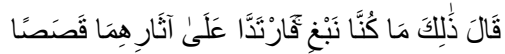

Moses said: "That is the place we are looking for." Then both of them returned, following their original path. "

That is the place we were looking for. Then both of them returned, following their original path."

When Moses and his students arrived there, they met with Khidhir as Allah explained:

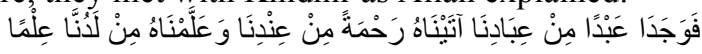

Then the two of them met a servant among our servants, whom We had given him mercy from our side, and whom we had taught him knowledge from our side. [15, p. 300]

When the two met with Khidhir, at that time he was in a state of pure white robes. The Prophet Moses also said hello to him. Then Khidhir answered his greeting and asked, "Where does this greeting come from on earth that has no welfare? Who are you"? The Prophet Moses answered: "I am Moses".[16, p. 4/144]

Khidir asked again, "Moses of the Children of Israel?" The Prophet Moses answered, "Yes ...!" I came to see you so that you can teach some of the knowledge that God has taught you. "

The words of the Prophet Moses to Khidhir as explained in the Qur'an are:

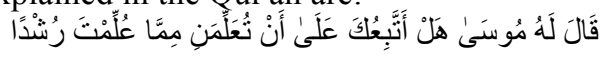


Moses said to Khidhir: "Can I follow you so that you will teach me the true knowledge among the sciences that have been taught to you?". [17, p. 4/448]

And the Prophet Moses still showed his determination to Khidhir that he would be patient and not violate his teacher's orders. Moses also said:

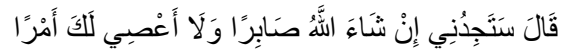

Moses said: "God willing, you will find me as a patient person, and I will not oppose you in any matter of affairs".

And finally, the sincere desire of Moses to learn to get a welcome and acceptance from Khidhir by submitting conditions:

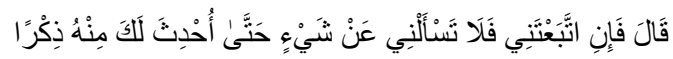

He said: "If you follow me, do not ask me anything until I have explained it to you".

So after a dialogue between Moses and Khidhir, where Moses agreed with what was asked by Khidhir that he should not comment on what he would see during his studies studying Khidhir until Khidhir himself told him. [18, p. 3/326]

\section{The Science of Moses and the Science of Khidhir in the View of Isyari Sufi}

The question arises of what knowledge does Khidhir have that Moses did not have, so Allah ordered Moses to learn it directly from Khidhir. And why not Allah alone taught it through revelation to him and is there a difference between the knowledge that Moses had and the knowledge that Khidhir had.

The majority of the interpreters of Sufi religious commentators argue that the knowledge possessed by Khidhir is the knowledge that is not possessed by Moses, namely the science of ladunni taken from verse 65 of the letter Al و " and "And we have taught him knowledge from our side (ladunni science). [19, p. 16/442]

Among the commentators who are shufi-style is Ibn Ajibah who in his interpretation "Al Bahrul Madid" said when he interpreted the verse:

$$
\begin{aligned}
& \text { وقوله تعالي: (و علمناه من لانا علما) العلم اللاني: هو الذي يفيض على القلب من غير اكتساب و لا تعلم, قال عليه الصلاة }
\end{aligned}
$$

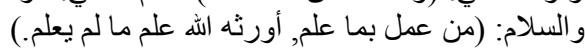

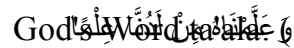

): is Ladunni Science whose knowledge is bestowed into the heart without effort and learning. Therefore the Prophet said: Whoever practices the knowledge that he knows, Allah will pass on the knowledge that he does not know yet. [6, p. 4/179]

Al Qadhi Mujiruddin bin Mahammad Al 'Ulaimi in his interpretation of Fathur Rahman Fi Tafsiril Qur'an which is also shufi patterned says something almost the same as Ibn Ajibah, namely:

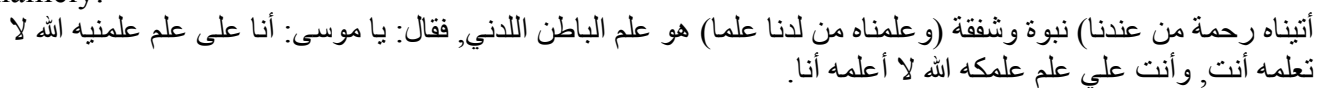

(We give mercy to him from our side) namely prophethood and compassion (We teach him from our side of knowledge), namely the inner knowledge of ladunni. Therefore, Khidhir said: 
"O Moses! I stand on the knowledge that Allah taught me that you do not know, and you stand on the knowledge that Allah teaches to you that I do not know.[20, p. 4/198]

This ladunni science as explained also by Imam Al Harawy in his book, he said:

"The science of ladunni is the knowledge that Allah bestows into the heart without any cause from a servant, and without him studying the proposition, therefore it is called ladunni

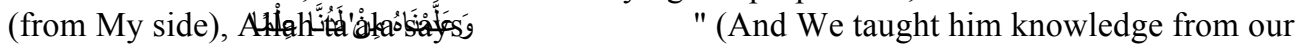
side). However, this science is more specialized than other sciences, therefore this ladunni science is based on Allah Subhanahu, such as Baituhu which is His house (Ka'bah), Naaqotuhu namely His Camel (miracle of the Prophet Sholeh), Baladuhu namely the lands Him, 'abduhu namely His servants and so forth.. [21, p. 1/991]

Sheikh Al Qusyairi in his commentary Lathaiful Signs said:

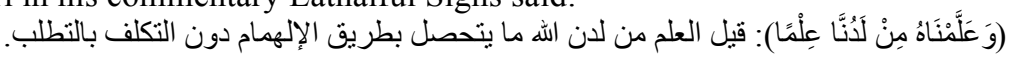

"It is said that it is a knowledge that comes from the side of God, which is obtained through inspiration without bothering to look for it." [22, p. 2/227]

Likewise Ismail Haqqi in his interpretation of the shufi style "Ruhul Bayan" said:

$$
\begin{aligned}
& \text { فال (و علمناه من لدنا علما) علما خاصا و هو علم الغيوب و الإخبار عنها بإذنه تعالى على ما ذهب إليه } \\
& \text { ابن عباس رضي الله عنهما أو علم الباطن. }
\end{aligned}
$$

"Allah said," (And we taught him knowledge from our side) special science, namely occult knowledge and news about occult matters with the permission of Allah ta'ala as viewed by Ibn Abbas or inner science ".[23, p. 1/34]

In the interpretation of isyari Bahrul Ulum the work of Sheikh As Samarkandi is also explained:

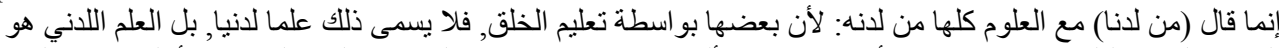

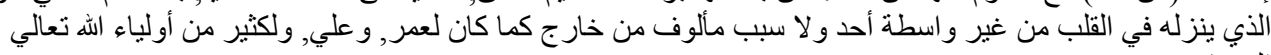

$$
\begin{aligned}
& \text { المرتاضين. }
\end{aligned}
$$

Verily Allah says: (From Our side), although all knowledge is from His side, because some of the knowledge was obtained through the intercession of human teaching, then such knowledge, is not called the science of ladunni, but the science of ladunni is the knowledge that Allah sent down into the heart without the mediation of anyone and the usual cause comes from outside himself, as happened to Umar bin Khattab, Ali ibn Abi Talib, and most of the saints of Allah who used to do riyadhah ruhiyah.[19, p. 16/441]

\section{Three Ladunni Sciences That Moses Learned From Khidhir}

The knowledge that Moses learned from Khidhir is all knowledge taught in real practice in the realities of life.

The first knowledge learned by the prophet Moses to Khidhir he learned was in the middle of the sea. That is when Moses was invited to walk towards the sea by Khidhir. When they reached the shore they looked for a ship to travel the ocean. And it turns out that they met a fisherman who knew Khidhir so they gave him a ride for free. Because Moses walked with Khidhir, Moses was given a free ride.

So began a conversation between Khidhir and Moses that the knowledge they both had was insignificant compared to Allah's knowledge. In the speaker, it was clear that Khidhir's 
laughter before Allah where he did not feel that his knowledge caused him to be arrogant but still believed that above all that there was Allah Who Knew everything.[7, p. 63]

It was while on the ship that Khidhir began his first lessons with the prophet Moses. Khidhir got under the ship and was followed by Prophet Moses. And what Khidhir did that made Moses amazed. It turned out that Khidhir went down under the ship and made a hole in the ship. Of course in the knowledge of the prophet Moses that what Khidhir did was a crime in the view of sharia of the prophet Moses.[24, p. 411]

So Moses immediately commented and denounced what Khidhir was doing and said: Why did you make a hole in the ship that caused the people on the ship to drown. Didn't they give a ride for free but why did their ship have a hole in it.

That is the view of the prophet Moses, which of course Khidhir had strongly suspected that Moses would deny it because the knowledge of the prophet Moses had not yet reached the true nature of perforating the ship. But it is not the time for Khidhir to tell Moses the reason he perforated his ship. Khidhir only rebuked the prophet Moses on the conditions agreed by them both that Moses was not allowed to ask about something before being told the reason. So that Moses was admonished why he could not be patient and wait for what reasons Khidhir did.

Moses just realized his promise that he was not allowed to ask questions until he explained why. So Moses apologized for forgetting to fulfill his promise not to ask questions before they were explained. And Moses also asked Khidhir not to give him heavy things in his studies.

And it turns out that Khidhir as a gentle and patient teacher forgave the prophet Moses for his forgetfulness. The reason the Prophet Moses argued with his forgetfulness was also commented on by the Prophet with his words: That Moses at the beginning did this because he forgot.

Then after that, it turned out that the ship was not damaged and caused the drowning of the people who boarded it. It was evident that Khidhir and Moses got off the ship without anyone knowing and feeling that their ship was leaking.

So Moses returned to follow Khidhir on the next journey. And it turned out that the next trip was tougher than the first. That is when they got out of the ship and they met a boy who was playing. Then immediately Khidhir met the child and killed him, without knowing the reason by the Prophet Moses.

Of course, this second science is heavier than the first. If the first one is to make a hole in the ship, which doesn't necessarily endanger the person riding it, but this time without needing a long time, a young child was killed for no apparent reason. So this time Moses saw that what Khidhir had done this time had also deviated far from the shari'ah studied by the prophet Moses, namely that it is forbidden to kill a child who is not yet mature, especially if he does not commit murder. So Moses immediately commented and said: Have you killed a soul who is still clean for no reason, then you have committed a great sin.[25, p. 358]

For this second time, Moses commented and asked with full awareness and did not forget. Because according to Moses what the pious servant had done was too much.

So Khidhir reprimanded Moses for the second time by saying the same thing except that he added the word you to confirm to Moses that he was impatient and rushed to comment and blame Khidhir. Khidhir said: did not I tell you that you really will not be able to be patient with me.

Because Moses had twice broken his promise to Khidhir that if he studied with him, he had to be patient to see what he was doing, so he explained the reason. So Moses promised for the third time that if he asked about anything the third time then Khidhir could stop his journey with Moses.

So the pious servant still forgives Prophet Moses and the journey of studying continues. 
After 2 previous events, this time they came to a village. And it turns out that they ran out of supplies of food and drink so that both of them were hungry and thirsty. So they asked to be entertained by the villagers but apparently, none of the villagers entertained and respected them both. Even though the villagers should have a generous attitude and respect the guests. But it turns out that the village where the two of them went to had bad morals, namely miser and did not want to respect guests and help people who were in trouble.

Amid difficulties, they both were in the village where the people were stingy, it turned out that when they went around the village they found a sloping wall and almost collapsed.

Seeing the wall, it turned out that the pious servant was upholding the almost collapsed wall. Even though the wall is in the village area. So when they were hungry and thirsty and the people they came to were people who were stingy and did not like to help people who were in trouble, Moses that what Khidhir was doing was an act that was not right in Moses's view. Khidhir should have asked these residents to ask for wages so they could buy food and drinks because they were travelers who ran out of food and drinks. So Moses commented not in the form of a question but the form of a suggestion by saying: "If you want, of course, you can erect the wall by asking for a fee".[7, p. 45]

It seems that Moses's last words also meant a violation of his promise not to ask questions and comment before he explained why the pious servant's reason was to erect a wall that was about to collapse.

So according to Moses's request, if he violated for the third time, Khidhir could stop the journey of the prophet Moses to seek knowledge from Khidhir.

Therefore Khidhir said: This is a separation between myself and yourself. This was after Moses broke his promise the third time. Then Khidhir said I would explain to you the explanation for the actions I did that you were impatient with.

So Khidhir revealed the secret science of essence which he already knew from Allah which Moses did not know of. If Moses knew it, he would have done what Khidhir did.

The first reason was explained by Khidhir that the ship he had punctured belonged to poor fishermen, where they work and live in the ship. And that is the source of their livelihood. Meanwhile, before them was a tyrannical king who took all the ships he met in the sea. So to save the poor fishing ship, Khidhir made a hole so that there was disgrace or disability in the ship. And it turns out that the ship was visited by the tyrannical king's army.

But when they found out that the ship they were going to take was imperfect because they found a hole under the ship. So they failed to take the ship. So what Khidhir was doing was essentially saving the ship by deforming it. And using perforating that is a strong reason not to be taken by the wrongdoing king.[26, p. 343]

As for why Khidhir killed a child who was playing. This is because the child, in Khidhir's knowledge, is based on what he knows from Allah, he is an infidel and acts arbitrarily towards his parents and endangers his believing parents. Because this child gets older it can cause both of them to disbelieve. And Allah wants to replace a child who is holier and more compassionate towards his parents.[25, p. 377]

As for the wall they encountered in the village where the people were stingy, that wall was a wall that fenced off two orphans where their father was a pious man. The father put the treasure under the wall in the hope that when his son grows up he can find the treasure himself. So Allah sent Khidhir to guard the property of a pious father whose thanks to his goodness, Allah guarded his property which he would inherit to his descendants. And if the wall collapsed and was discovered by the people who were stingy and did not respect guests and did not want to help people in distress, their property would be lost and taken by the villagers.[27, p. 234] 
Those are the three reasons that Khidhir did base on the knowledge he has given by Allah as Allah revealed and We give mercy from our side and We teach knowledge from our side.

If Moses knew the reasons for these actions, Moses would certainly have confirmed what the pious servant did. But because Moses was impatiently waiting for an explanation of the reasons behind this action, Moses's journey to study from Khidhir was completed with Moses finding only 3 knowledge of the sciences he had learned from the pious servant Khidhir.[7, p. 70]

\section{Isyari's Interpretation in the Story of Moses and Khidhir}

As we know that the knowledge of ladunni in the story of Moses and Khidhir is based on the argument from Surah Al Kahf verses 60-82. And specifically, this term is taken from verse 65 which reads: "And We give mercy from Our side and We have taught knowledge from Our side".

If we open the commentary book with the isyari shufi pattern, we will surely find them interpreting verse 65 of the Al-Kahf letter, indicating the existence of ladunni knowledge.

This is clearly explained by the interpretation of the verse from several of the above isyari interpretations, such as the interpretation of Al Bahrul Madid Fi Tafsiril Qur'anil Majid by Ibn Ajibah, which uses ladunni knowledge in interpreting verse 65 of the letter Al Kahf.[6, p. 4/179]

Likewise, we find from Tafsir Fathur Rahman Fi Tafsiril Qur'an by Al Qadhi Mujirudduin also interpreted verse 65 by using the term ladunni knowledge.[28, p. 4/197]

We find contemporary interpretations such as Sheikh Mutawalli Asy Syarawi when interpreting verse 65 of Surah Al Kahf using the term ladunni knowledge. He said: Then he says afterward: (And we taught him from we know) that is, from what is not through the messengers, so they call it secular knowledge as if there is no blame on God Almighty to choose a slave of His servants and bless him with special knowledge from behind the prophethood. [29, p. 15/8954]

Likewise, Sayyid Quthub in his interpretation of Fi Zhilalil Qur'an interpreted using the term ladunni science. He said: However, the pious man knows that his knowledge is not human knowledge with clear causes and near results, but he is one side of the unseen ladunni knowledge that Allah taught him according to the level that Allah will and because there is a wisdom that Allah wills too.[30, p. 2279]

So the term ladunni science has been known from classical isyari interpretations even in modern interpretations.

Where: Where is the knowledge of ladunni is the knowledge that Allah teaches directly to the heart of a servant without going through angels.

Where is the ladunni knowledge of the prophet Khidhir in his story with Moses? We can answer these questions from 3 events of their journey, namely:

When Khidhir perforated the ship and Moses denied the act. Khidhir made holes in the ship they were given free of charge to ride on. Logically, this action is a despicable act. Why boarding a ship for free has a hole in it. Isn't that repaying good for evil. And perforating means causing the people in the ship to drown, because the water will enter the ship and cause the ship to sink and so will the passengers in the ship.[17, p. 4/444]

But why did Khidhir keep making holes so that the prophet Moses protested? This was because Khidhir had knowledge that Moses did not know. According to the knowledge he 
knew from Allah that there was an unjust king who would seize every ship they found in the sea. And there is no other way to save the ship than to deform the ship. Because the unjust king will not take it unless a ship that is still good and can sail. Now, with a little hole, the ship is not suitable to be a ship that sails well. And it turned out to be true what Khidhir had done, namely when the king's troops came with their army to seize the ship, finally, it was canceled after they learned that the ship had a hole. So Khidhir's actions were appropriate because he had saved the ship from being seized. If there is a slight hole then it can be fixed by the owner. So it is better to repair a little damaged than to lose the ship that is their source of livelihood at sea. In Islam what Khidhir has done is called "seeking the remembrance of two losses".[31, p. 66]

That is the knowledge of ladunni that the prophet Moses learned from Khidhir on the first occasion because no one knows the danger of the evil king of the wrongdoing except Khidhir. And Khidhir was told by Allah about it and he was ordered by Allah to save that poor fishing ship. And these fishermen are poor but pious. This is known by their respect for Khidhir by providing free rides. So what Khidhir did was to do good to the poor fisherman because he saved their ship. And Khidhir did not make a big hole in it, but what a small hole that made a bit of a defect. And the proof that the passengers did not drown was when Moses and Khidhir finally got off on the beach. And the ship's seizure event occurred not long after they got off the ship. So the ship after that stopped at the beach and did not sail, and after that, the seizure incident occurred and the shipowner knew that their ship had a little hole so they only had to repair and patch it but their ship survived the seizure.[28, p. 3/198]

As for the second ladunni knowledge that the prophet Moses obtained from Khidhir was in the incident of killing a child, according to the knowledge of the prophet Moses, the act of killing was sinful, especially when it was committed against a child whose reason was unclear. According to Khidhir's knowledge, the act of killing a child is justified by Allah, because based on the knowledge that Khidhir can directly from Allah through ladunni knowledge is that the child is disbelief in Allah and is an injustice to both his believing parents. And this child is left alive will endanger the faith of his parents by inviting both of them to disbelief and abuse them both. So Khidhir was given a task by Allah and received permission from Allah to kill the child. So what Khidhir was doing was essentially saving the child and the child's parents. Because the child was prevented by Khidhir from committing a bigger sin when he was an adult. And when he died when he was not yet baligh, his reckoning was easier when he was an adult when he died. And to both parents, their faith was saved and of course, Allah will replace him with a child who is holier and more loving to his parents.[25, p. 3/345]

The third knowledge that the prophet Moses received from Khidhir was the incident of erecting a wall that had almost collapsed. If according to the logic and knowledge of the prophet Moses, what Khidhir did was considered a futile act and had little benefit for them both. Khidhir should have erected the wall asking for wages from villagers who are stingy and disrespectful to guests and help people in trouble. With these wages, according to the Prophet Moses, they could eat and drink because they both needed food and drink after a tiring journey. It is based on the knowledge possessed by the prophet Moses. But it is different with Khidhir's knowledge that he got from Allah. Allah has only informed Khidhir and is not known by others. That the wall is the wall of an orphan house under which there is their inheritance which is kept by their pious father. So because of his goodness, Khidhir was ordered by Allah to erect the wall so that it did not collapse. Because the wall collapses, the inheritance buried under it will be known by the miserly residents, and it is feared that some of them will steal it. So thanks to the goodness of this father and the future of his descendants, Allah saved him through Khidhir's intermediary by upholding the wall. And Allah with the 
knowledge that Allah taught him that when the child is an adult then they will unload the hidden treasure and take it for their benefit. So that the pious father's intention was achieved with the help of Khidhir.[29, p. 15/9855]

Those are the 3 knowledge that Moses got after Moses couldn't wait to know the reasons why Khidhir did all that.

And that is the essence of ladunni knowledge or intrinsic knowledge because with this knowledge Khidhir has done good and his efforts to save 3 groups of humans is a form of obedience to Allah Ta'ala.

\section{Conclusion}

From our previous discussion, we can make the following conclusions :

The knowledge of ladunni is also studied in depth in the interpretation of isyari shufi. The commentators of the isyari shufi tafsir explain in their interpretation that the story of Moses and khidhir shows the existence of ladunni science.

In the story of Moses and Khidhir, there are 3 ladunni sciences that the prophet Moses learned from Khidhir. In 3 what Khidhir did, it appears that Khidhir had a mission. For example, a mission to save the economy of poor fishermen. Both missions are to save the faith of parents from disobedient and infidel children. The last or third mission is to save the future of the orphan. 


\section{References}

[1] A. R. As-Sa'di, Taysir Al-Karim Ar-Rahman fi Tafsir Kalaam Al-Mannaan, 2nd ed. Riyadh: Dar As Salam, 2002.

[2] Ahmad Mukhtar Umar, Mu'jam Lughah Arabiyah Muasirah. Alamul Kutub, 2008.

[3] As-Shabuny, Shofwah At Tafasir, 4th ed. Beirut : Lebanon: Dar Al Qur'an Al Karim, 1981.

[4] Al-Alusy, Ruhul Maany Fi Tafsiril Qur'anil Adzim Wa Sab'al Matsany, 1st ed. Beirut: Lebanon: Muassasah Ar Risalah, 2010.

[5] A. Thobathobai, Tafsir-Mizan. Beirut: Lebanon: Muassasah Al A'lam, 1997.

[6] I. Ajibah, Al Bahrul Madid Fii Tafsiril Quranil Majid. Cairo: Darul Kutub Al Ilmiyah, 1999.

[7] A. Z. Abidin, Rihlah Min Ajlil Ilmu. Egypt: Jaridatul Ahram, 1989.

[8] I. H. Al-Asqalani, Fathul Baary Bisyarhi Shahih Al Bukhari, 1st ed. Beirut: Lebanon: Dar Ar Risalah Al Alamiyah, 2013.

[9] I. Al Jauzy, Tafsir Tadzkiratul Al-Aryb Fii Tafsir Al Gharib. Beirut: Libanon: Dar Al Kotob Al-Ilmiyah, 2004.

[10] Al-Tirmidzi, Tuhfatul Ahwadzy Syarah Jaami' At Tirmidzi. Beirut : Lebanon: Dar Al Fikr.

[11] Aras'any, Rumuzul Kunuz Fii Tafsiril Qur'anil Aziz, 1st ed. Mekkah: Maktabah Al Asady, 2008.

[12] I. Athiyyah, Al Muharrar Al Wajiz Fi Tafsir Al Kitab Al Aziz, 1st ed. Beirut : Lebanon: Dar Al Kotob Al-Ilmiyah, 2001.

[13] Sayyid Hawa, Al Asas Fi At Tafsir. Dar Al Salam, 2009.

[14] Ats Tsa'laby, “Al Kasyfu Wal Bayan Fi Tafsir Al Qur'an.” Dar Al Kotob Al-Ilmiyah, Beirut : Libanon, 2004.

[15] M. bin A. Al Makky, Al Mu'in Ala Tadabbur Al Kitab Al Mubin. Beirut: Lebanon: Dar Al Nawadir, 2010.

[16] A. K. Najmuddin, At Ta'wilatun Najmiyyah Fii Tafsiril Isyari Shufy. Lebanon: Dar A1 Kotob Al-Ilmiyah, 2009.

[17] A. Naisabury, Garaaibur Al Qur'an Fii Raghaibu Al furqan. Beirut : Lebanon: Dar Al Kotob Al-Ilmiyah, 1996.

[18] A. Mawardy, An Nukatu Wal Uyun Tafsirul Mawardi, 1st ed. Beirut : Lebanon: Dar Al Kotob Al-Ilmiyah, 2010.

[19] A. Harary, Tafsir Haqaiqul Ruh Wa Al Raihan. Mekkah: Dar Athouqi An Najah, 2001.

[20] Mujiruddin, "Fathur Rahman Fi Tafsiril Qur'anil Karim." Dar Al Fikr, Beirut: Libanon, pp. 190-2010, 2019.

[21] Al-Harawy, Manazilus Sairin. Beirut : Lebanon: Dar Al Kotob Al-Ilmiyah, 1988.

[22] A. Qusyairi, Lathaaif At Tafsir. Beirut: Lebanon: Dar Al Kotob Al-Ilmiyah, 2007.

[23] I. Barusawi, Ruhul Bayan Fii Tafsiril Qur'an, 1st ed. Beirut : Lebanon, 2018.

[24] A. F. Al Kholidy, Min Qashash Al Sabiqin Fi Al Qur'an, 1st ed. Beirut: Lebanon: Dar Al Qalam, 1989.

[25] A. F. Al Kholidi, Al Qashash Al Qur'ani. Beirut: Lebanon: Dar Al Qalam, 1989.

[26] Muhammad Mutawalli Asy-Syaarawi, Qashashul Anbiya. Egypt: Dar Al Quds, 2006.

[27] Ibnu Katsir, Qashas Al-Anbiya. Egypt: Dar At thiba'ah Wan Nansyr Islamiyah, 1997.

[28] Mujiruddin, Fathur Rahman Fi Tafsiril Qur'anil Karim. Beirut : Libanon: Dar An Nawaadir, 2019.

[29] M. Asy-Sya'rawi, Al Khawatir Al Imaniyah, 10th ed. Dar El Islam, 2010.

[30] S. Quthub, Fi Zhilal Al Qur'an. Beirut: Libanon: Dar As Syuruq, 2003.

[31] Hamdi Ganiim Sulaiman, "Qishatu Moses Alaihis Salam.” Dar Al Qalam, e, 2003. 